\title{
Internationalization in Japanese Education
}

\author{
MARIE ROESGAARD
}

\section{Introduction}

In recent decades Japan has been extremely successful in its business transactions and has manifested itself to the world as an economic super-power. This success has often been attributed in part to the Japanese educational system. By achieving very high general standards of education (over 90 per cent of an age cohort receive higher secondary education) Japan has created a well educated workforce which is able to read, write and understand fairly complicated explanations. This means that the majority of the workforce can change work procedures relatively quickly and also that workers are able to make well founded suggestions for improvements.

The present educational system in Japan is built upon the post-war reforms of 1946-1952. With these reforms an effort was made to create democracy in education, more individually oriented education and an education with more parental and teacher involvement and less central or ministerial control than had formerly been the case. The system was modeled on the American 6-3-3-4 system with nine years of compulsory education. This meant a six-year elementary school (shoogakkoo), a three-year middle school (chuugakkoo), a threeyear high school (kookoo) and a four-year university (daigaku). Compared to most Western countries the curriculum is vast and demanding, at least until the end of high school education, and Japanese students are known to perform extremely well in international achievement tests. ${ }^{1}$ Also literacy rates are high despite the large number of characters necessary for reading Japanese. ${ }^{2}$ In short, Japanese education is apparently well suited to teach basic skills such as reading, writing and calculus.

One might ask why anyone would think of reforming a seemingly well adapted educational system such as the Japanese. It certainly serves its purpose with respect to the teaching of basic skills, but it is no secret that the present system does have its problems. 
The horror stories of high rates of teenage suicides and masses of children getting their personalities warped by a harsh, standardized system are common in the world press.

On a general basis the educational system is criticized for not being internationally oriented, i.e., not able to teach the students how to place themselves in a world-wide context and more specifically, for neglecting the teaching of things like communicative skills in foreign languages and for being too rigid to be able to welcome foreign students and Japanese students returning from abroad. ${ }^{3}$ This was part of a broader discussion on how Japan was to participate in international activities and on how it could be more open to the world, not least in terms of trade. It had been argued that part of the structural impediments on the activities of foreign traders in Japan was related to the ethnocentricity of the Japanese, their lack of knowledge of other countries and cultures, as well as to tariffs and their indigenous distribution systems. International harmonization and an international consciousness among the Japanese was thus seen as the answer to a whole range of problems besides the educational ones.

The term international orientation was one of four key-phrases in four reports issued between 1984 and 1987 by the National Council for Educational Reform (NCER). This council was established by then prime minister Nakasone Yasuhiro in 1984. Among certain groups of politicians and business people there was a growing fear that Japan would not be able to hold a strong position in the world economy if she did not put more emphasis on research and on educating creative workers and researchers. Thus the objective of the council was described in the following terms:

[The Council is] to advise the prime minister on basic strategies for necessary reforms with regard to governmental policies and measures in various aspects, so as to secure such education as will be compatible with the social changes and cultural developments of our country. ${ }^{4}$

The council was composed of representatives from business, higher education, employer and employee organizations, public administration, the arts, elementary and secondary schools and the Japanese Olympic Committee. Also, there was a number of specialists attached to the council, who could be called upon for advice. The majority of the council members were what the opposition called 
prime minister Nakasone's "own" men, which meant that the outcome of NCER's deliberations was in no way a surprise to the opposition.

Groups in opposition to the government's educational policy and to NCER were notably the teachers' organizations Japan Teachers' Union (JTU) and All Japan Teachers' Union (ATU) - (JTU split in November 1989 and many of its members went to ATU) - and also research groups connected to JTU and other groups like the Japanese Academic Society on Education (Nihon Kyooiku Gakkai), parents' and citizens' groups. However, these groups had little or no access to influence the NCER. It was the Prime Minister and the NCER who single-handedly set the agenda and decided what was to be the issues in the official reform debate.

Reading the NCER reports one will soon find what appears to be quite obvious discrepancies between the rhetoric of the reports and the reforms that have been implemented inspired by the reports. The rhetoric does not match the political practice. The interpretation of the reports comes into focus, because different actors in the debate interpret the reports differently according to their backgrounds and hence draw very different pictures of the nature of the NCER proposals.

There was hardly any contact between the opposition and NCER. The official side set the agenda, decided on the topics and the participants. The opposition - if heard - was heard only at a stage where the vital decision of what could be discussed had already been taken. The issue of internationalization was seized by NCER and the government as a reaction to the charges that Japan was too closed and did not participate in the world community, as well as as a remedy for the lack of international impact of Japanese research.

\section{What Is Internationalization?}

One of the four central key phrases of the NCER reform proposals was "internationalization" or kokusaika as it was termed in Japanese. Prime Minister Nakasone in a speech delivered at the beginning of the NCER deliberations, requested that NCER give advice on how to make education compatible with the "trends of internationalization in various sectors." ${ }^{6}$ Unlikely though it may seem, internationalization became associated with nationalism in Japan. As a representa- 
tive of the teachers' organization ATU deftly put it using a pun, the internationalization of the NCER is not kokusaika but kokusuika (ultranationalism). ${ }^{7}$

Mouer and Sugimoto in their book Images of Japanese Society devoted a chapter to the analysis of the meaning of internationalization in Japanese terms. ${ }^{8}$ The term was an all time favourite in advertising and in the mass media, and they found that to most Japanese it signified something positive. However, discussions of internationalization tended to centre on activities rather than ends. Instrumental activities such as learning English, travelling overseas, teaching more about foreign cultures in Japanese schools and the like, were steps toward an undefined goal, which it turned out to be impossible to make the Japanese define further.

Mouer and Sugimoto found two dominating goals for internationalization as reflected by the media. One was the goal of smooth promotion of Japan's national interests, mainly in economic terms. This was the view held by the establishment, the Liberal Democratic Party (LDP), business, in short, the conservative camp. This view entailed a demand for understanding from foreigners and tended to explain economic frictions in terms of cultural misunderstanding unfortunate clashes in cultural style. Hence, the establishment deemed it important for successful internationalization to instruct foreigners in the Japanese culture and language, while also ensuring that the Japanese themselves were well aware of their cultural heritage. ${ }^{9}$ As we shall see, these formulations were taken over by the NCER.

Apparently, internationalization was more about widening knowledge and understanding of Japan abroad, than about teaching foreign cultures and languages at home. As Peter Dale explained it, "spreading knowledge of Japan abroad was seen as an indispensable device for bolstering Japan's national security," and arguments for larger investments in language programs and culture centres abroad were buttressed by suggestions that "the coming economic war will be a war of cultures in which the way foreigners interpret the Japanese mind will be decisive."

This projection of culture abroad constituted part of the "internationalization" efforts. Quite apart from the ethnocentric aspect of this projection, it was also used as a cover-up device. In Peter Dale's words: 
Discussions on economic and diplomatic conflicts are entangled in dubious references to the decisive differences in mentality and culture, a tactic which often relies upon the outsider's ignorance, or his inability to verify such claims. Often the argument of culture is used astutely and consciously to deflect attention from the real problems at issue, or to rationalize a refusal to concede ground on issues that primarily involve economic interests. ${ }^{10}$

NCER provided a concrete example of this economic aspect of the opinion held by the establishment on the issue of internationalization. In the second NCER report it was said that Japan's economy was prosperous due to close economic relations with all countries in the world. Since such economic relations were accompanied by human relations and direct personal contacts, the occasions when what NCER termed "cultural frictions" occured also increased. NCER stated that such frictions should be considered normal in an international society and that they should be used as energy for vitalizing Japanese society. ${ }^{11}$

To sum up, using Peter Dale's concepts, internationalization in the establishment version had nationalistic ingredients insofar as it was used as a device in an economic war - or at least in economic relations. This enculturation of politics - that is, making the strengthening of Japan's culture and economy the goal of internationalization - made it difficult to argue with the concept of internationalization for both Japanese and others.

The anti-establishment forces or the progressive camp, tended to see internationalization as a means to secure world peace through international brotherhood or, for the most radical, even a world government. This group was motivated by a perceived need for changing Japan's role in the world community, involving a change of Japanese government as well, the last aspect of course being the main source of disharmony with the establishment. ${ }^{12}$

Though not quite as radical as to demand a world government the teachers' organization ATU on the issue of internationalization said that genuine international understanding and consciousness was a necessity for the sake of peace and the world environment. A country could not take care of this on its own, ATU stated, so a more international orientation would be necessary for ensuring peace and a clean environment. ${ }^{13}$

The emphasis is clearly placed on what might be termed "human" values rather than on economy. The opposition's view of interna- 
tionalization was propagated in a proliferation of publications from the teachers' organization, bearing titles such as "Listen to the Voice of Hiroshima" (Hiroshima no koe o kikoo), "For the Children's Happy Future" (Kodomotachi no shiawase na ashita no tame ni) and badges with inscriptions such as "Children's greatest treasure is peace" (Kodomotachi no saikoo no takara wa heiwa desu).

Morita Toshio, formerly the director of the Citizens' Institute for Educational Research affiliated with JTU, clearly also found the motivations of the establishment dubious. He argued that NCER's version of internationalization would rekindle Japanese militarism. and imperialism and that the hidden ambition of the Japanese ruling class was a "pax Japonica" hegemony over Asia and the Pacific. He emphasized that a scientific and balanced approach to the realities of world history, in which reform proposals based on theories of "Japanese culture" were firmly rejected, was absolutely necessary to counter this movement towards nationalism. ${ }^{14}$

Morita was supported by his successor on the director post, Igasaki Akio, who, in an interview with Mark Lincicome in 1989, described NCER's policy on internationalization as economically inspired, Japan-centred and more nationalistic (kokusuika) than internationalistic in orientation. Igasaki also emphasized that the proper goals of internationalization were to secure world peace, oppose the proliferation of nuclear weapons, support environmental issues and contribute to the advancement of education in developing countries. ${ }^{15}$

As Mouer and Sugimoto concluded from their findings the ordinary citizen probably did not distinguish between these conflicting goals of internationalization. He or she was probably spurred mostly by self interest and therefore could swing either toward the conservative or toward the progressive definition depending on what seemed to promise most gain for the citizen. ${ }^{16}$

The two different interpretations of the nature of internationalization stood out clearly in the debate. The establishment needed internationalization to ensure that Japan would not stop developing its economy and its share of the world market, while also maintaining cultural integrity. The anti-establishment, in this case mainly the teachers' organizations, were preoccupied with avoiding the horrors of war, with attaining world peace and understanding, and in the final analysis, with overthrowing the government. This conflict quite naturally led to accusations that the kind of internationalization 
Marie Roesgaard

NCER was talking about was mainly of domestic or even nationalistic concern.

\section{Internationalization in NCER Terms}

NCER described the concept of internationalization as a concept which varied with the conditions. It was said that the concrete contents of internationalization could change according to the needs of the times, so that a policy based on today's conditions may be out of date tomorrow. NCER described internationalization as a process of accumulation of people's daily practices. ${ }^{17}$

With a definition like this, one should clearly not expect any quickacting medicine which would internationalize Japanese education overnight. NCER underlined that it would be a process of repeated trial and error, groping to find the way and attempting to change the consciousness of the Japanese. Therefore one should not be afraid of failure but persist in the efforts, NCER stated. ${ }^{18}$

The immediate reason for the emphasis on internationalization was in particular to be found in problems at university level. NCER in its description of the state of education at the time, from the internationalization point of view, primarily dealt with the universities, saying that they had few educational and research activities of a standard high enough to earn them international reputation. Also, Japanese universities had failed to respond to the need for internationalization in respect to such areas as exchange of researchers and the teaching of foreign languages, NCER claimed. ${ }^{19}$

NCER stated that the Japanese people ought to contribute internationally, to be tolerant of other cultures while not loosing sight of their own. Continuing the line of argument from the previous identification of the main source of problems, NCER saw an upgrading of education and research, especially at universities, as the main remedy. The goal was to make these institutions more open to the international community. It was clear from NCER's initial statements that the target area was the universities, but there was also the already mentioned concern that too much internationalization might make the Japanese loose their national identity. This was clear from the repeated provisions made in relation to internationalization: 
From now on the Japanese must have a deep understanding, respect and affection for Japanese culture as well as be tolerant of other cultures [...] It must be understood that a good world citizen (yoki kokusaijin) is also a good Japanese (yoki nihonjin), and our education must teach people love for the country (kuni o aisuru kokoro) and a firm sense of the individuality of the Japanese culture as well as deepen the knowledge of the culture and traditions of all foreign countries. ${ }^{20}$

NCER further stated that people should strive to gain the ability of reviewing the situation in Japan relative to the values and traditions of other cultures. ${ }^{21}$ Apparently, profound knowledge of Japanese culture and a realization of the relativity of Japanese values vis-à-vis other values were a prerequisite of international acceptance in NCER terms. The wording employed by NCER in this section was quite emotional as is clear from expressions such as "have a deep understanding, respect and affection (keiai) for Japanese culture" and later "love for the country." 22 The term keiai has been translated as simply "love" in the English version of the report, but this fails to deliver the nuance of "respect" which is also implied in the term. This particular term was the one used in connection with the emperor in earlier more nationalistic days when one was to show keiai (respect and affection) towards the emperor.

This particular emotional tone appealed to people's national feelings, to the eternal xenophobic fear, so well-known in many countries, that the peculiarities of the culture would disappear in the contact with larger units of culture. Whether or not this fear is reasonable is not the issue. Here it is limited to an observation that fear of being swallowed up by an unidentified "international community" apparently prompted NCER to emphasize Japanese culture and history in the context of internationalization. Not only was this interpreted as nationalism by the opposition, it was also accused of backstabbing the whole plan of internationalization and gave rise to the kokusuika rhetoric of the opposition. The emphasis on Japanese culture and Japaneseness made sense in the context of internationalization only if one saw the aim of internationalization as being that of furthering one single country's international influence, namely that of Japan, and not that of creating a brotherhood of man, the opposition would argue. There was given no allowances for the idea that probably every existing country will try to define itself in an international context and define its international role. The latter is 
no doubt part of the motivation, but at the same time there can be little doubt that the emphasis was on what would further a conservative Japan and its economy.

NCER's attitude to internationalization centred on domestic needs. First internationalization was more or less left to an accumulation process which would enable official Japan to do very little actively because internationalization was to be "an accumulation of people's daily practices." Then the issue of internationalization was described as mainly a device for heightening the quality of research and education at universities. Internationalization was not for the compulsory and secondary levels, it would seem, where time apparently was to be spent on learning how to become a "good Japanese" in order to later become a "good world citizen." The NCER rhetoric left no doubt that internationalization was primarily a domestic matter and that international contacts were mainly to take place at higher levels of education.

\section{How to Internationalize}

The five main concerns in NCER's internationalization efforts were the universities, fostering a "good" Japanese, the education of Japanese children abroad, how to receive Japanese children who had been abroad for some time and, finally, the admittance of more foreign students into Japanese educational institutions.

The universities' international role was described as follows:

The university is international by nature and scientific research is basically undertaken by all mankind. If our country is to gain respect and trust in an international arena and is to make contributions to peace and progress in the world we must, based on higher education of an international standard, further intensify international exchange in culture and science. ${ }^{23}$

NCER proceeded to propose methods for making the universities more international concentrating on exchange. Exchange of researchers, especially the young ones, exchange programs between Japanese and foreign universities, joint international research projects at university level with special consideration to developing countries, stimulation of international activities of learned societies and international exchange of scientific information were among the proposals. 
NCER saw it as the task of the universities to develop international-minded citizens through strengthening their programs related to international understanding and cooperation. This continued the trend from the emphasis on the exchange efforts in which it was repeated over and over again that existing efforts had to be strengthened and reactivated. Apparently, it was perceived that many of the exchange programs, which had already been established, did not work satisfactorily.

NCER called for immediate action in the field of post graduate education. Many students and young researchers had not been provided with the opportunity to study abroad, so in this respect the programs had to be improved immediately in order to secure an international standard of future research. Also, NCER recommended that the complicated government formalities involved when teachers and researchers of national universities wanted to go abroad should be simplified and be made more flexible. Combined with an increase in the number of foreign researchers accepted at Japanese universities, particularly young researchers, and more favourable conditions for receiving foreign teachers, internationalization of the university staff was envisaged to take place. ${ }^{24}$

Individual exchange agreements between Japanese and foreign universities should be encouraged, NCER felt, and to help such steps NCER recommended that Japanese universities should have more autonomy with respect to financial and personnel management. Also, the universities should set up independent funds for international exchange.

International cooperation on particular projects was also encouraged by the NCER, and it was emphasized that cooperation should be undertaken with both advanced and developing countries. Regarding the latter, NCER mentioned that such projects were already under way in the form of a "core university system." This system designated a number of cooperating universities in Japan and a given developing country undertaking joint research, exchange of researchers and the like. The same system was to provide an opportunity for young researchers in developing countries to obtain a doctor's degree from a Japanese university. ${ }^{25}$

Though NCER would always include the developing countries in its internationalization proposals, the very fact that the exchange was to take place in advanced fields of education and science ironically 
would preclude the most underdeveloped nations from participating. ${ }^{26}$

Apparently concerted efforts were to be made aiming at the internationalization of the universities, but the university staff and students were not asked for an opinion. Of course some of the bodies involved in the coordination had university staff representation, but the universities as such were clearly not seen by NCER as autonomous organizations with their own opinions and wishes. The Ministry of Education was considered to be the representative of the universities in this proposal and the Ministry would have much influence on university exchange efforts if NCER had its way. Obviously, the Ministry could not be left out entirely as it would always have to be involved as provider of the funds needed for realizing the programs. But NCER had the Ministry of Education so high on its priority list that the question of the direct involvement by the universities as responsible for formulating the exchange programs was never raised.

After having dealt with the university issue in this manner, NCER turned to the question of how to cope with internationalization more generally, stating that Japan was entering an era of "new internationalization" in which she could not survive being isolated from the international community. ${ }^{27}$

In this line of argument the economic aspect was very clear. The growth Japan had experienced was based on exchange with other countries and through this economic growth the exchange of persons had also become more frequent. This could cause the abovementioned "cultural frictions" which were to be perceived as normal phenomena in an international community, to be used as energy for vitalizing Japanese society. NCER envisaged increased exchange of persons between countries and saw the resulting "heart-to-heart" contacts (kokoro no fureai) as an insurance of international understanding.

Though the goal may have seemed to be determined by economic considerations, NCER emphasized that the efforts at internationalizing should not only be economic but also educational, scientific and cultural. Not only the Japanese educational system but also the minds of the Japanese were to be opened to the international community, though as we have already seen NCER at the same time found it important to foster a good Japanese (yoki nihonjin). First, students should be well informed about Japan and then they should 
be made aware of the different customs and values present in the world. In particular, the lack of knowledge of neighbouring Asian countries was regretted. ${ }^{28}$ The logical conclusion must be that internationalization was to come as the second step - after educating a "good Japanese" at the elementary and secondary levels.

Cooperation and the acknowledgement of differences were the key words in the rhetoric of the NCER. The differences between cultures rather than similarities were emphasized, and indeed this fact was much criticized by the opposition.

The responsibility for the realization of this NCER type of internationalization was seen as resting with what was ambiguously termed the "people":

The main agent in the realization of this new internationalization is us, the people. One by one we must understand the problems and strive at solving them by letting grass roots efforts grow into a national movement. But no immediate realization of reform should be expected. ${ }^{29}$

The quest of internationalizing Japan clearly was to be undertaken with a long-term perspective. The idea of an internationalization growing from grassroots level was acceptable to all parties in the debate, though the motivations for this differed. Igasaki Akio of the Citizens' Institute for Educational Research and Suzuki Isao, director of the government-supported National Institute for Educational Research (Kokuritsu Kyooiku Kenkyoojo) in interviews with Mark Lincicome in 1989 agreed on the necessity for internationalization to be realized through grassroots efforts, but disagreed on the significance of this. For government-supported Suzuki this meant working within the school system by strengthening the role of the teacher, while for JTU-affiliated Igasaki it meant circumventing government interference and manipulation by turning to non-governmental organizations. ${ }^{30}$

Clearly, the opposition wanted to separate internationalization from government influence and use it to promote general human values rather than particular Japanese economic interests. But because the opposition is rather vague in its statements on the subject it is difficult to imagine a concrete version of their brand. of internationalization. The biggest difference in the two positions in the debate lies in the fact that for the NCER-party internationaliza- 
Marie Roesgaard

tion is an economically useful concept while for the opposition it is more related to universal human values.

\section{Returnee Children and Japanese Children Overseas}

A substantial number of pages in NCER's reports was devoted to treating the particular question of how to receive children returning to Japan after a long stay abroad and the question of how to educate them while abroad. ${ }^{31}$

In future Japan we must think of the returnees (kikokushijo) as a valuable asset. Basic to the education of these children should be efforts by the Japanese schools to appreciate the particular advantages they have acquired abroad both upon and after admission to a Japanese school. ${ }^{32}$

This was a reformulation of the policy concerning the returnees which had held sway until then. Until NCER redefined it, the policy had been one of "de-internationalizing" the returnees, reinforcing their Japanese consciousness and coping with the stigma of their foreign experience. The novelty of NCER's approach was the reformulation of the significance of foreign experience. It was no longer - officially at least - a stigma but a "valuable asset." ${ }^{133}$ Returnees were considered useful in roles such as interpreters, international ambassadors of Japan, consultants etc., functioning within the scope of jobs in which international contacts would be essential.

Despite the acclaimed value of children's foreign experiences it still seems that a disproportionately large part of the internationalization chapters in NCER's reports was devoted to returnees. In 1985 there were less than 40,000 Japanese children of school age living abroad - in 1991 the figure was slightly over 50,000 - and this was out of a total figure of more than 15 million children of school age in Japan. $^{34}$

The reasons for the attention are many, but one is probably that the parents of the returnees have often been quite influential and active on their children's behalf. The parents are usually welleducated and hold or have held influential positions. Other reasons may be that the returnees are not only useful to the NCER as a tool in internationalization and a demonstration of some activity in the area, but also they are of concern in NCER's attempts to maintain the cultural integrity of the Japanese. While being redefined as an asset 
they are also still very often looked upon as not entirely "ordinary Japanese."

NCER recommended that measures should be taken to facilitate the return to Japanese schools of returnee children, and in high school and university special places and special admission procedures should be secured. Even non-Japanese students who did not speak or understand Japanese should in time be allowed to enter Japanese schools and universities, NCER suggested.

NCER further recommended that schools accommodating returnee children or foreign children should be enabled to have specially trained teachers for counselling and Japanese language instruction. Also teachers with foreign experience and foreign teachers should be utilized. But there were limits to the integration. A leeway for segregation was offered with the proposal of establishment of new schools for the purpose of mixing Japanese children, returnees and foreign children. This was to promote research and methodological and theoretical development in the area of internationalization of education. Obviously such schools could also be used as means of containing the impact of international contacts. NCER also felt that the Japanese educational system should take measures for accepting the attendance by a Japanese high school student at a high school in a foreign country as equivalent to attendance at a high school in Japan and finally, graduates from existing international schools in Japan were to be granted qualification for advancing to Japanese educational institutions of a senior level, provided they complete particular suitable courses. ${ }^{35}$

For Japanese children staying overseas, NCER called the following to attention:

As for the education of Japanese children in foreign countries, emphasis on the basic training as a Japanese must continue and while taking into account the circumstances in the host country and the educational prospects for those children on returning to Japan, we recommend a basic policy of giving them as much experience of the host country as possible. ${ }^{36}$

Given the heavy reliance on factual knowledge obtained through rote learning required for entrance examinations in Japan, there is probably not one single country in the world which has an educational system that could not be said to be detrimental to the chances of a Japanese child of passing an entrance examination back in Japan. 
For all practical purposes, NCER with its proviso that "the educational prospects of those children on returning to Japan" was to be taken into account ruled out attendance at a local school. In practice, this provision meant that a Japanese child overseas would attend a Japanese school if possible. This school may add more or less subjects relating to the host country, as for example extra language classes or excursions.

NCER did try to remedy this situation by suggesting that the above-mentioned special provisions for entrance be supplied and by emphasizing the desirability of making the most of the foreign experiences of such children, but in practice it is still often regarded a liability in the examination competition to have been abroad for too long. ${ }^{37}$

Another problem with these ideas, which was also acknowledged by NCER, was that the Japanese schools overseas tended to be very similar to the schools in Japan, focusing on high school entrance examinations and maintaining a very rigid policy of school management, as was evident in their reluctance to accept foreign (local) children, a fact that NCER greatly regretted. Rather, NCER said, Japanese schools overseas should cultivate in Japanese pupils a sense of international citizenship, be more open internationally by admitting foreign nationals and actively strive to improve their schools for the future. ${ }^{38}$

\section{Foreign Students in Japan}

Another measure for internationalizing the Japanese system of education in NCER's plans was accepting more foreign students. This was expected to have the desirable effect of internationalizing as well as upgrading the level of education and research, promoting international understanding and cooperation and increasing Japan's contribution to the development of qualified human resources for the world. To aid this NCER suggested that legal controls and various educational and practical obstacles be removed. Again we see how international exchange in Japan seems to be limited to higher education though many countries have good experiences with exchange at high school level.

In very flowery terms the ideal situation was described. Japan's future image would be that of a country where 
...excellent foreign people will be pleased to come and study and work in science, art and other areas of Japanese society so that, after their return home, they may contribute to the development of their own country. In other words, it is envisaged that Japan may be a country associated with the blooming of the talent of foreign people. ${ }^{39}$

The fact prompting NCER to suggest more foreign students in Japan was that the number of foreign students in Japan was actually smaller in Japan than in many other advanced countries. The reasons for this in NCER's analysis were legion. First, there was an inadequate structure in universities and in other places for accepting foreign students as well as limited opportunities for learning Japanese abroad. In NCER's analysis, a basic prerequisite for Japan to get more foreign students in the future was that higher education and scientific research in Japan reached an international standard high enough to attract foreign students. ${ }^{40}$

This was a serious criticism, particularly as nearly 40 percent of the foreign students in Japan at the time had come to study in a postgraduate program. Graduate schools in particular were the target of NCER criticism and were said to be lacking in quantity as well as in quality.

To facilitate the situation of foreign students in Japan NCER proposed special courses at institutions of higher education for foreign students, enriched language teaching, new selection procedures for foreign students, preparatory courses, more flexible requirements for entrance into institutions of higher learning, home stays and "aftercare" - sending former students Japanese academic publications, re-inviting them to Japan, etc. Also, the level of information about Japanese education to students wishing to come to Japan should be improved, and NCER envisaged an increase of the number of foreign students in Japan to the level of 100,000 by the beginning of the 21st century. As there were slightly more than 33,000 foreign students enroled in Japanese universities in 1989, this would be a substantial increase. ${ }^{41}$

In general Japanese language instruction for foreigners received high priority. Methods, materials and Japanese language proficiency tests were to be improved and an examination for certifying teachers of Japanese as a foreign language was to be introduced. All this because of a perceived close relation between Japanese language and Japanese culture: 
Needless to say, the Japanese language and Japanese culture are in balance with each other and the language is connected to esteem for the culture and other Japanese matters. So, it is conceivable that with the increased number of foreigners learning Japanese their understanding of Japanese culture will also increase. Therefore it is important, in accord with the structures and policies of the country in question, to strive for introducing Japanese culture in foreign countries in order to advance the teaching of Japanese. ${ }^{42}$

Culture was described as the vehicle of language studies. NCER also pointed out the need for making a distinction between purposes for learning Japanese, namely between those learning Japanese as a tool of communication and those learning Japanese in order to study Japanese classics. This should be reflected in the teaching. Additionally NCER called for a more active promotion and involvement in the teaching of Japanese in foreign countries by providing teaching materials, sending Japanese teachers abroad upon request and establishing student exchange programs for mutual benefit. ${ }^{43}$ To sum up, the existing efforts were to be intensified while graduate school in Japan was to be made more attractive by means of higher quality.

\section{New Requirements of Japanese Education}

In the analysis of the Japanese educational system, NCER vehemently criticized foreign language education for placing undue emphasis on grammatical knowledge and reading comprehension, while neglecting the acquisition of practical conversation skills. The level of foreign language proficiency was rather poor for most Japanese students despite the amount of time spent on language instruction, NCER lamented. Emphasis should be placed on mastery of an international language as a tool for international communication.

To remedy this situation, NCER suggested the improvement of methods and materials along with a clarification of the objectives of language instruction - presumably a clarification entailing more emphasis on spoken language, but this is not clear from the context. Secondly, the English tests in university entrance examination should be improved so they may duly assess the abilities in listening, 
speaking, reading and writing. NCER also suggested that one might employ tests produced by bodies other than the university of which TOEFL ${ }^{44}$ is the most well-known. ${ }^{45}$

Further NCER remarked that teaching English alone was not sufficient:

The need for learning languages other than English must be emphasized. That is, the second language in university should be chosen not only from among French, German and Spanish, but also from among Asian languages. ${ }^{46}$

There was - and is - a geographical imbalance between Japan's location and the language studies pursued in Japan. A further clear indication of the imbalance in the academic pursuits of knowledge was evident in statistics NCER had found which showed that while the vast majority of Japanese students studying abroad were in Europe and North America, the majority of foreign students in Japan were from Asian countries. NCER concluded that Japanese students had to be made aware that countries other than those in Europe and North America had valuable things in which the Japanese ought to be interested, and NCER expressed its desire that the destinations of the Japanese students become more diversified. ${ }^{47}$

Part of the suggested internationalization efforts to be carried out by institutions of higher education in Japan, adding to the above suggestion of revised teaching methods and the acceptance of foreign students and staff, was a revision of the content and curriculum of higher education. As NCER saw it, university students did not have sufficient knowledge about foreign history, culture, social environment and other foreign affairs, despite the fact that they had been given many lessons in the subjects. NCER instead recommended the strengthening of regional studies, comparative studies, international relations studies and the like as part of the general education courses. This would require inter-disciplinary research and education so a re-examination of the existing structures of university education and research would be necessary. Knowledge about foreign classics, Chinese and Indian classics as well as Western, in NCER's view was also an indispensable element of international awareness.

A major element in NCER's efforts of internationalizing the Japanese was the desire to be "trusted and respected by other people" (shinrai to sonkei o kachitoru koto ga dekiru). This was to be achieved 
through understanding, international contributions in various fields and direct contacts between people. ${ }^{48}$

NCER apparently saw its mission in upgrading the status of Asian countries in the process of internationalizing Japan. But the exact purpose of this upgraded status and interest on the part of Japan was debatable, especially in the light of the overall formulation of NCER's policy for internationalizing Japanese education and in the light of the strong concern for not only recovering and nurturing Japanese values but also for introducing Japanese culture abroad. Remembering Morita's warning quoted above that the ruling class of Japan was aiming at a "pax Japonica" in Asia, it would not at all be unreasonable if the targeted Asian countries were to be somewhat wary of the motives behind the interest the Japanese professed to feel toward them.

\section{Conclusion}

The desire to be respected by other countries has been a strong factor in Japanese foreign relations ever since the opening of Japan in the middle of the nineteenth century. Initial treaties between Japan and other countries were very unequal as were most treaties between the advancing West and other areas of the world at the time. Japan had as one of its primary goals the acceptance by the United States and Europe of their equal status and a desire to earn the respect of those countries.

While Japan is by now doubtlessly respected as an equal (or sometimes even as a superior) in economic and judicial terms, there are still matters in which Japan is accused internationally of not living up to its responsibility. The United States expects Japan to take on more responsibility in military matters and in UN operations. The Japanese contributions to the developing world are also a matter which has received much criticism internationally, particularly from Asian countries who feel that the Japanese as fellow Asians and former conquerors have a special moral responsibility towards them. There is evidence that this criticism has been heard in NCER's emphasis on Asian countries in Japanese education and in the repeated references to developing countries. Japan must take up its social responsibility, its responsibility for world peace and harmony in order to gain respect from the international community. This is a 
message from NCER with which one would hesitate to disagree. However, the means of internationalizing and the covert nationalistic goals as perceived by the opposition are areas of concern.

The NCER proposals operated on both a public and a private front. That efforts at internationalization were necessary in all sectors of society was hardly a subject for debate, but the means and what was perceived by the opposition as the hidden agenda for furthering Japanese economic and nationalistic interests certainly were debated.

The domestication of internationalization and its relation to nationalism has made the term "internationalization" one of dubious meaning. As part of the NCER rhetoric it is an answer to international criticism of too little Japanese international engagement in areas other than trade. But, judging from an analysis of NCER's own explanations of the term, in practice it is mainly an internal Japanese matter of furthering economic development and creating national unity. Held up against the opposition's idea of internationalization as a prerequisite for peace and a clean environment one can hardly be surprised that the two opposing parties find it hard to discuss the matter with one another. As the NCER and the Ministry of Education are not obliged to discuss this with the opposition such as the teachers' organizations, there is little chance of establishing a consensus on the meaning of internationalization of Japanese education and the way to pursue it. The teachers' organizations will be the ones left unsatisfied because the Ministry of Education has every chance of realizing its policy, if not directly through the Japanese parliament, then through the use of "administrative guidance."

Marie Roesgaard teaches Japanese in the Department of Asian Studies, University of Copenhagen. The above article is a revised version of a paper presented at the second annual conference of the "State and Society in East Asia" Network, Gentofte, May 12-15, 1994

\section{NOTES}

1 Studies by Thorsten Husen ed., International Study of Achievement in Mathematics: A Comparison of Twelve Countries. Vol. 2 (New York: John Wiley and Sons,
1967) and Richard Lynn, Educational Achievement in Japan (Basingstoke, MacMillan Press, 1988) elaborate on this. 2 "99 percent literacy" is what is generally 
claimed in Japan. John De Francis among others criticises this quoting an official in the Ministry of Education who said that even though compulsory schooling provided people with a knowledge of 1,945 kanji they soon forgot to write all but 500 or so. This possibly meant literacy in reading but surely there would be illiteracy in writing. The fact that kana may be used for writing any word in Japanese provides a short-cut to literacy compared to Chinese, but still it is questionable whether the literacy rate is really so high as often claimed. See John De Francis, The Chinese Language, Fact and Fantasies (Honolulu: University of Hawaii Press, 1984), pp. 216-18.

3 Kawamura Kinji, ed., Discussions on Educational Reform in Japan (Tokyo: Foreign Press Centre, 1985), pp. 23, 40; Roger Goodman, Japan's "International" Youth (Great Britain: Clarendon Press, 1990), p. 94; Leonard J Schoppa, Education Reform in Japan: A Case of Intmobilist Policies (London: Routledge, 1991), p. 50.

4 Rinkyooshin (Rinji Kyooiku Shingikai), Kyooiku Kaikaku ni Kansuru Tooshin, (Tokyo: Ookurashoo Insatsukyoku, 1988), p. 5.

5 The three others were: respect for individuality, adaptation to the information society and establishment of a life-long learning system

6 Rinkyooshin, Kyooiku Kaikaku ni Kansuru Tooshin, p. 5.

7 Interview with Kawai Naoki, Head of Department of Education and Culture, ATU (Zen Nippon Kyooshokuin Kumiai), May 16. 1991.

8 Ross Mouer and Sugimoto Yoshio, Images of Japanese Society (England: Routledge \& Kegan Paul, 1986).

9 Ibid., pp. 380-383

10 Peter Dale, The Myth of Japanese Uniqueness (London: Routledge, 1986), p. 19

11 Rinkyooshin, Kyooiku Kaikaku ni Kansuru Tooshin, p. 129.
12 Mouer and Sugimoto, Images of Japanese Society, p. 382.

13 Interview with Kawai Naoki, May 16. 1991.

14 Morita Toshio, Rinkyooshin to Nihonjin Nihonbunka Ron (Tokyo: Shin Nihon Shuppansha, 1988), p. 12.

15 Mark Lincicome, "Nationalism, Internationalism and the Dilemma of Educational Reform in Japan," Comparative Education Review, Vol. 37, No. 2 (1993), p. 131.

16 Mouer and Sugimoto, Images of Japanese Society, pp. 380-3.

17 Rinkyooshin, Kyooiku Kaikaku ni Kansuru Tooshin, p. 324.

18 Ibid., p. 234.

19 Ibid., p. 7.

20 Ibid., pp. 15-16.

21 Ibid., p. 240.

22 Ibid., p. 15.

23 Ibid., p. 118.

24 Ibid., pp. 118-119.

25 Ibid., p. 119.

26 Walter Edwards, "Internationalization, Nihonjinron, and the Question of Japanese Identity," JALT Journal, Vol. 11, No. 2, quoted in Lincicome,"Nationalism, Internationalism and the Dilemma of Educational Reform in Japan," p. 133.

27 Rinkyooshin, Kyooiku Kaikaku ni Kansuru Tooshin, p. 129.

28 Ibid., p. 129.

29 Ibid., p. 130.

30 Mark Lincicome, "Nationalism, Internationalism and the Dilemma of Educational Reform in Japan," p. 131.

31 See Roger Goodman: Japan's "International" Youth (Oxford: Clarendon Press, 1990), and Merry White: The Japanese Overseas: Can They Go Home Again? (New York: N.Y. Free Press, 1988).

32 Rinkyooshin, Kyooiku Kaikaku ni Kansuru Tooshin, p. 130.

33 Lincicome, "Nationalism, Internationalism and the Dilemma of Educational Reform in Japan," p. 136. 
34 Statistics Bureau, Japan Statistical Yearbook (Tokyo,1992), p. 671; Monbushoo, Education in Japan. A Graphic Presentation (Tokyo: Gyoosei, 1989), p. 23.

35 Rinkyooshin, Kyooiku Kaikaku ni Kansuru Tooshin, pp. 236-237.

36 Ibid., p. 130.

37 Goodman, Japan's "International" Youth, pp. 2-3.

38 Rinkyooshin, Kyooiku Kaikaku ni Kansuru Tooshin, p. 131.

39 Ibid., p. 132.

40 Ibid., p. 132.

41 Statistics Bureau, Japan Statistical Yearbook, p. 671 .

42 Rinkyooshin, Kyooiku Kaikaku ni Kansuru Tooshin, pp. 135-136.

43 Ibid., p. 239.

44 TOEFL stands for Teaching Of English as a Foreign Language.

45 Rinkyooshin, Kyooiku Kaikaku ni Kansuru Tooshin, pp. 134-135, and p. 238.

46 Ibid., p. 239.

47 Ibid., pp. 237-238.

48 Ibid., pp. 136-137. 